\title{
liguleless1 encodes a nuclear-localized protein required for induction of ligules and auricles during maize leaf organogenesis
}

\author{
Maria A. Moreno, ${ }^{1-3}$ Lisa C. Harper, ${ }^{2}$ Roger W. Krueger, ${ }^{1,4,5}$ Stephen L. Dellaporta, ${ }^{1}$ and \\ Michael Freeling ${ }^{2}$ \\ ${ }^{1}$ Yale University, Department of Biology, New Haven, Connecticut 06520-8104 USA; ${ }^{2}$ University of California, Department \\ of Plant Biology, Berkeley, California 94720 USA; ${ }^{4}$ DeKalb Plant Genetics, Mystic, Connecticut 06355 USA; ${ }^{5}$ Present \\ address: Monsanto, St. Louis, Missouri 63167 USA.
}

The maize ligule and auricle are structures on the maize leaf that develop at the boundary of the sheath and blade. In the absence of liguleless1 (Ig1) gene expression, ligule and auricle are not formed, and the blade-sheath boundary does not develop as an exact line between sheath and blade. By using the Activator (Ac) transposable element as a molecular tag, a novel $\lg 1$ allele, $\lg 1-\mathrm{m} 1$, was isolated and cloned. Analysis of somatic revertant sectors confirmed that the LG1 gene product functions in a cell-autonomous fashion. cDNA cloning as well as RT-PCR analysis of the LG1 mRNA indicate that the Ig1 gene is expressed at very low levels in the ligular region of developing maize leaf primordia, perhaps as early as plastochron 6 or earlier. Cellular localization studies in a heterologous system indicate that the LG1 product localizes exclusively to the nucleus. The predicted amino acid sequence of the LG1 protein is largely novel but contains an internal domain of 77 amino acids with significant similarity to a domain present in two recently identified SQUAMOSA PROMOTER-BINDING proteins 1 and 2 (SBP1 and SBP2) in Antirhinum majus.

[Key Words: Ligule; auricle; leaf development; gene tagging; $A c$; green fluorescent protein]

Received November 7, 1996; revised version accepted January 31, 1997.

The maize leaf consists of three general parts: the blade, the sheath, and the ligular region. The ligular region lies between the blade and sheath and consists of the ligule and auricle (Fig. 1A). The ligule is a fringe of epidermal tissue rising from the adaxial surface of the leaf where the auricle and sheath adjoin. The auricle is a pair of wedge-like structures that extend from the midrib to the margins of the leaf and serve as a hinge between the blade and the sheath, permitting the blade to adopt a more horizontal growth attitude.

Histological and genetic mosaic analyses of ligule development have shown that the ligule is solely derived from the epidermal layer while the auricle is formed from both epidermal and underlying mesophyll tissues (Sharman 1941, 1942; Hake et al. 1985; Becraft et al. 1990). The first morphologically visible step in ligule and auricle development is a localized increase in anticlinal divisions on the adaxial surface of the leaf primordia, resulting in the preligular band (Becraft et al. 1990; Sylvester et al. 1990). The ligule then arises out of the plane of the leaf via periclinal divisions /Sharman 1942; Becraft

${ }^{3}$ Corresponding author.

E-MAIL maria.moreno@yale.edu; FAX (203) 432-3854. et al. 1990) The preligular band develops after the differentiation of the mid- and lateral veins in the primordium but before a visible differentiation between sheath and blade (Sharman 1942). Ligule outgrowth and auricle elaboration occur in the context of the overall basipetal differentiation of the leaf. Because the leaf epidermis grows by anticlinal divisions, the process of ligule formation is of particular interest because it requires the coordination of a small group of cells to reorientate the plane of cell division and develop into a structure different from that from which it arises.

In maize, several mutants identify genes that appear to be involved in the normal development of the ligular region (Becraft et al. 1990; Freeling 1992). Perhaps one of the most informative genes is the liguleless1 ( $\lg 1)$ gene, located on the short arm of chromosome 2. A plant homozygous for the recessive null allele $1 g 1$-Reference $(\lg 1$ $R$ ) has leaves that lack ligule and auricle and have a less well-defined blade-sheath boundary (Emerson 1912). Close examination has shown that $l g 1-R$ mutants never accomplish the longitudinal anticlinal divisions necessary for proper preligular band formation; thus, the block in ligule development is at or before this step (Sylvester et al. 1990). 
Clonal analysis has revealed that the $1 g 1-R$ phenotype acts in a cell-autonomous fashion in epidermal tissues. In the adaxial epidermis, the LGl protein is involved in the formation of the ligule and auricle epidermis, whereas in the underlying tissues, it is involved in the development of the auricle. Thus, the gene's action is not specific to a particular cell type. It has also been proposed that the LG1 gene product functions at the receptor end of the process whereby the make-ligulemake-auricle signal is propagated cell to cell, received, and transduced (Becraft et al. 1990; Becraft and Freeling 1991).

An Activator $(A c)$-induced allele of the $\lg 1$ gene was isolated using a novel transposon-tagging strategy (Dellaporta and Moreno 1994a). By using Ac as a molecular tag, we have cloned the $\lg 1-\mathrm{m} 1$ mutation and used flanking genomic sequences to obtain genomic and cDNA clones of the $\lg 1$ gene. Analysis of germinal revertants from $\lg 1-\mathrm{m} 1$ shows that the reversion phenotype is correlated with the excision of $A c$ from the $1 g 1$ locus. RTPCR experiments show that LG1 mRNA is expressed in the developing ligular region of primordial leaves. Analysis of $\lg 1 \mathrm{cDNA}$ clones suggests that the $\lg 1$ gene encodes a protein with novel domains but with distinct homology to a 77-amino-acid region present in the SQUAMOSA promoter-binding proteins 1 and 2 (SBP1 and SBP2) of Antirhinum majus, which is known to bind the promoter of the MADS box gene SQUAMOSA (Klein et al. 1996). Cellular localization experiments indicate that a LGl fusion protein localizes to the cell nucleus.

\section{Results}

\section{Isolation of an Ac-induced $\lg 1$ mutant}

Using an Ac-mediated gene-tagging strategy (Dellaporta and Moreno 1994a), a $\lg 1$ mutant associated with the $A c$ element was recovered. The mutant, designated $\lg 1-\mathrm{m} 1$, was recessive and had leaves that lacked a proper ligular region and displayed an upright habit of growth (Fig. 1C). Crosses of $1 g 1-\mathrm{m} 1$ homozygotes to $\lg 1-R$ homozygotes produced $100 \%$ mutant progeny, indicating that $\lg 1-\mathrm{m} 1$ is an allele of $\lg 1$.

The lesion in the $\lg 1-\mathrm{m} 1$ allele is associated with the insertion of an $A c$ element, as determined by genetic tests. Approximately 100 mutant plants were testcrossed as females with pollen containing the Dissociation (Ds) tester allele $r$-sc:m3. The ears from these crosses contained kernel progeny that mostly showed a coarsely spotted aleurone phenotype, indicating that the mutant plants were homozygous for a transposed $A c$ (tr-
$A c)$ element. The occasional kernels showing a colorless or finely spotted phenotype were expected because $A c$ remains unstable. These exceptional kernels represent an increase in $A c$ copy number (finely spotted) or loss of $A c$ activity (colorless). Nonmutant siblings were either heterozygous for $A c$ or did not contain $A c$ activity. These results indicate that the $1 g 1-\mathrm{m} 1$ allele is correlated genetically to the presence of an $A c$ element.

\section{$\lg 1-\mathrm{m} 1$ is somatically and germinally unstable}

Homozygous $1 g 1-\mathrm{m} 1$ plants display revertant sectors of wild-type ligule and/or auricle in the mutant ligular region, a characteristic of $A c$-induced mutations. Sectors of ligule were only observed on the adaxial surface of the leaf, whereas auricle sectors were evident on the abaxial surface (see Fig. 2). The sectors observed were clonal in nature and have perfectly defined boundaries. This is in agreement with the $\lg 1$ gene function acting in a cellautonomous manner as described previously by Becraft and coworkers (1990).

Germinal instability was observed as the appearance of occasional wild-type plants in populations homozygous for the $1 g 1-\mathrm{m} 1$ allele and in populations heterozygous for $\lg 1-\mathrm{m} 1 / \lg 1-R$ alleles. To determine the frequency of germinal reversion for the $A c$ element at $\lg 1$ $m 1$, $\lg 1-m 1$ homozygotes were crossed to $\lg 1-R$ homozygotes to produce $100 \%$ heteroallelic $\lg 1-\mathrm{m} 1 /$ lg1- $R$ progeny. A total of 2768 seeds of this progeny were sown in sand benches, and the plants were scored for wild-type phenotype. Reversion to wild type was seen at a frequency of $1.9 \%$. These revertants were saved for further analysis and were shown to be the result of premeiotic excision of the Ac element from one of the two homologs restoring $\lg 1$ wild-type function, as discussed below.

The recessive $\lg 1-\mathrm{m} 1$ phenotype cosegregates with a unique Ac element

Using Southern blot hybridization analysis on DNA from families segregating for the $\lg 1-\mathrm{m} 1$ phenotype, we found that the $1 g 1-\mathrm{m} 1$ allele cosegregated with a single Ac element. A 900-bp fragment of unique internal $A c$ sequences ( $\mathrm{Ac} 0.9$; see Fig. $3 \mathrm{~A}$ ) was selected as a probe based on its inability to hybridize with most $D s$ elements. Because the $\lg 1-m 1$ allele was isolated in an inbred genetic background, W22, the Ac element could be identified among the cryptic $A c$-like sequences present in the maize genome using methylation-insensitive en-

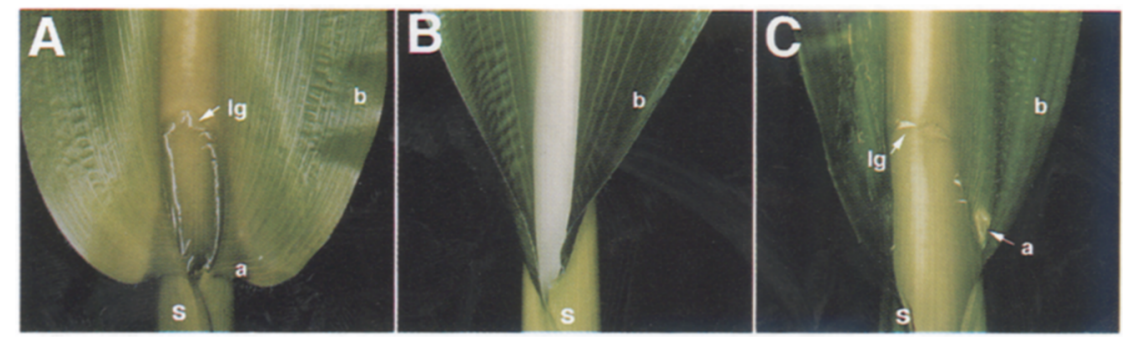

Figure 1. Examples of the ligular region of wild-type and $\lg 1$ mutant leaves. $(A)$ The ligular region of a wild-type leaf; $(B)$ the ligular region of a $\lg 1-R$ leaf; $(C)$ the ligular region of a $\lg 1-\mathrm{m} 1$ leaf. (lg) Ligule; (a) auricle; (s) sheath; (b) blade. 


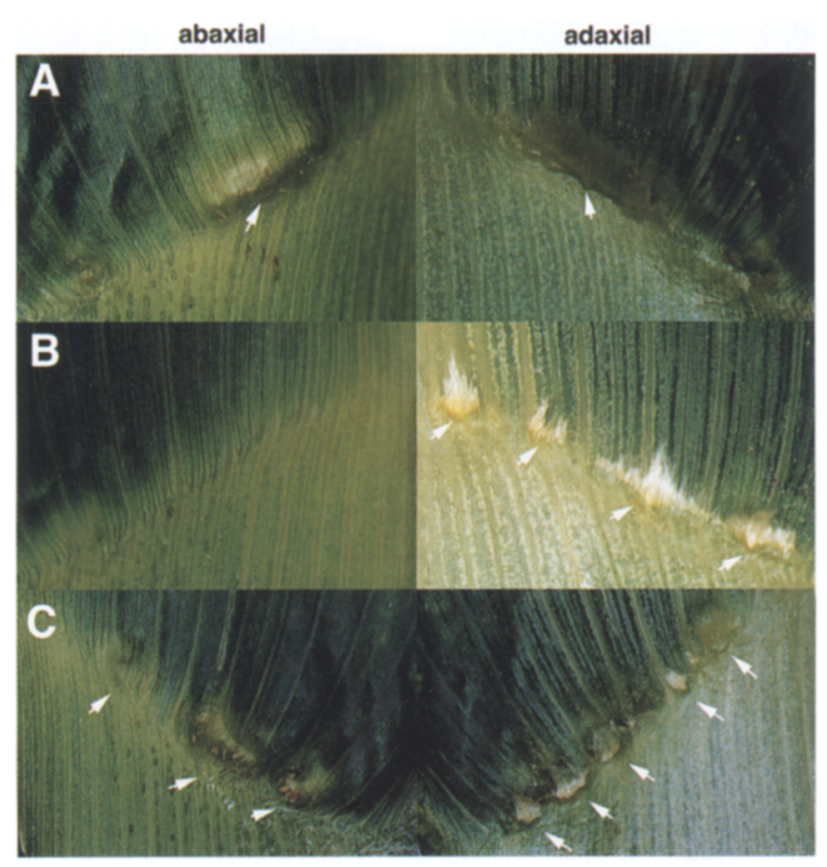

Figure 2. Examples of $1 g 1-m 1$ somatic sectors. (A) An example of a revertant somatic sector that gives rise to a patch of ligule and auricle in the proper adaxial and abaxial surfaces of the leaf. This is an example of a somatic revertant sector that has occurred in both the epidermis and underlying tissue, thus affecting all layers. $(B)$ An example of revertant somatic sectors that give rise to ligule patches only on the adaxial surface of the leaf. There are no corresponding auricle sectors on the abaxial side of the leaf. These sectors represent an example in which $A c$ excision event has affected only the epidermal layer. $(C)$ Examples of somatic revertant sectors, in which the $A c$ has excised giving rise to sectors containing ligule as well as auricle patches, or auricle patches only. The arrows indicate locations of the sectors.

zymes. Southern hybridization analysis with the Ac0.9 probe showed a constant hybridization pattern of five cryptic bands in W22 inbred DNA (Fig. 3A, lane 1). In our analysis of DNA samples of plants segregating for the lg1-m1 phenotype, a new EcoRI Ac-hybridizing band of $14.5 \mathrm{~kb}$ in size was detected. This novel band was present in all of the plants that showed a liguleless phenotype (lanes 2-5) and was detected in only two-thirds of the wild-type siblings (lanes 6-9). Figure 3A shows an example of the results of this analysis.

Genomic DNA from a homozygous $1 g 1-m 1$ plant was used to generate an EcoRI size-fractionated genomic library. Approximately $8 \times 10^{6}$ primary recombinants were screened with the Ac0.9 probe, yielding 170 positive signals. DNA from plaques corresponding to these signals was isolated, restricted with $E c o \mathrm{R} 1$, and analyzed by Southern hybridization with the Ac0.9 probe to detect clones containing the $14.5-\mathrm{kb}$ fragment associated with the $\lg 1-m 1$ mutation. Of 170 primary positive clones analyzed, only one, $\lambda \operatorname{lgl}-\mathrm{ml}$ contained the expected $14.5-\mathrm{kb}$ insert. A restriction map of $\lambda \lg 1-\mathrm{m} 1$ is shown in Figure $3 \mathrm{~B}$. The restriction map of this clone indicates that it contains the expected region of $A c$ with $\sim 12 \mathrm{~kb}$ of flanking genomic DNA.

To determine whether $\lambda \lg 1-\mathrm{m} 1$ corresponded to the lg1-m1 allele, genomic DNA flanking the Ac element was used to probe Southern blots of mutant and wildtype sibling plants. The probe used was S0.8, a $0.8-\mathrm{kb}$ Sall genomic fragment (see Fig. $3 \mathrm{~B}$ ). The $\mathrm{S} 0.8$ probe crosshybridized with the 14.5-kb EcoRI fragment in mutant plants identified previously by the Ac0.9 probe, indicating that the clone was likely to represent the transposed Ac cosegregating with the $1 g 1-\mathrm{m} 1$ mutation.

\section{Molecular analysis of $\lg 1$ mutant alleles}

The contiguous genomic probes B4.7 and $\mathrm{H} 6.7$ identified in Figure $3 \mathrm{~B}$ were used to probe Southern blots of restricted DNA from each of three $\lg 1$ mutant alleles: the $1 g 1-R$ allele, available from the Maize Genetics Stock Center, and two independent Mutator (Mu)-induced lg1null alleles (lg1-6198 and $\lg 1-K 16)$, recovered from directed tagging experiments. Neither of these three mutants contains sequences homologous to either probe (data not shown), suggesting that these mutation events may represent deletions within the $1 g 1$ locus. Further analysis of the $\lg 1-K 16$ and $\lg 1-6198$ deletions and their progenitor alleles with the probe umc53 (Maize Genetics Stock Center) indicates that these two alleles carry the expected progenitor RFLP alleles and that these deletion events were independent of each other, as well as of the lg1-R allele. These results confirm that our genomic probes are, part of the $\lg 1$ gene.

To further confirm that sequences corresponding to the $\lg 1$ gene had been cloned, several germinal $\lg 1^{+}$|wildtype) revertants derived from $1 g 1-\mathrm{m} 1$ were analyzed. Fifty-two germinal revertants were recovered independently from crosses of $\lg 1-\mathrm{m} 1 / \lg 1-\mathrm{m} 1$ to $\lg 1-R / \lg 1-R$. Genomic DNA was isolated from these revertant plants, digested with SstI, and subjected to Southern analysis with the S0.8 probe (Fig. 3B). Results are shown in Figure 3C. DNA from plants homozygous for the progenitor wild-type $\lg 1$ allele contain a 10-kb SstI fragment (Fig. $3 \mathrm{C}$, lane 1). DNA from plants homozygous for the $1 g 1-R$ allele show no hybridization to this probe, because this allele is a deletion of the $\lg 1$ locus, as described previously (Fig. 3C, lane 3). DNA from plants heteroallelic for the $\lg 1-\mathrm{m} 1 / \lg 1-R$ alleles contain the expected $14.5-\mathrm{kb}$ fragment, which is attributable to the presence of the $A c$ element (Fig. 3C, lane 2). Plants carrying a revertant $1 g 1$ $\mathrm{m} 1$ allele $\left(\lg 1^{*} / \lg 1-R\right)$ show only the $10-\mathrm{kb}$ SstI band (Fig. $3 \mathrm{C}$, lanes 4-9). These results indicate that the phenotypic reversion of the $\lg 1-\mathrm{m} 1$ allele is associated with the loss of the $4.5-\mathrm{kb}$ genomic fragment detected with genomic probes derived from the $\lambda \lg 1 \mathrm{~m} 1$ clone.

\section{Isolation and analysis of $\lg 1 \mathrm{cDNA}$ clones}

A cDNA library was constructed from mRNA isolated from dissected developing ligules at plastochrons 4-7 (P4-P7). Approximately, $8 \times 10^{6}$ primary recombinants were screened with the probe H6.7 (Fig. 3B), yielding 
A

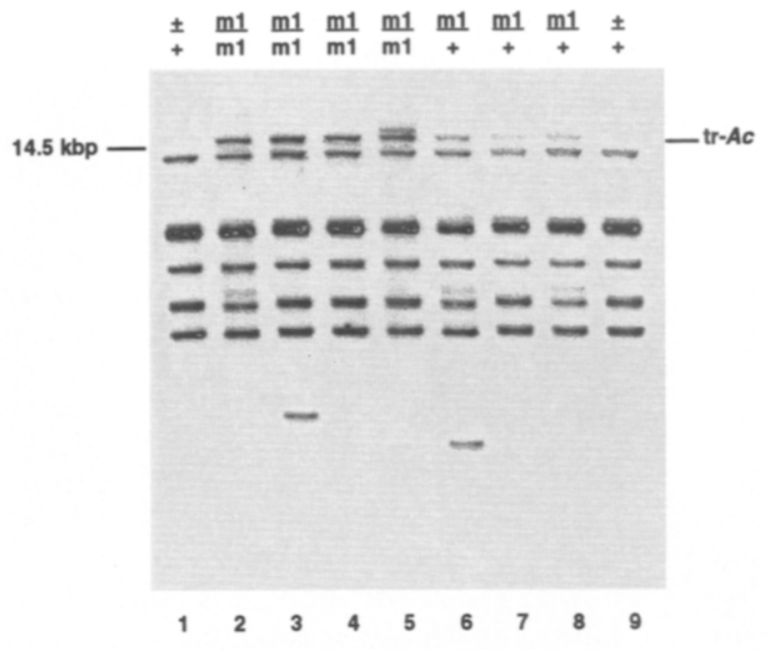

Figure 3. A new $\lg 1$ allele is associated with the insertion of an $A c$ element. $(A)$ Genomic DNA was isolated from plants segregating for the $\lg 1$ phenotype and from the parental W22 inbred line. The DNA was digested with the enzyme EcoRI and analyzed by Southern blotting with the

B

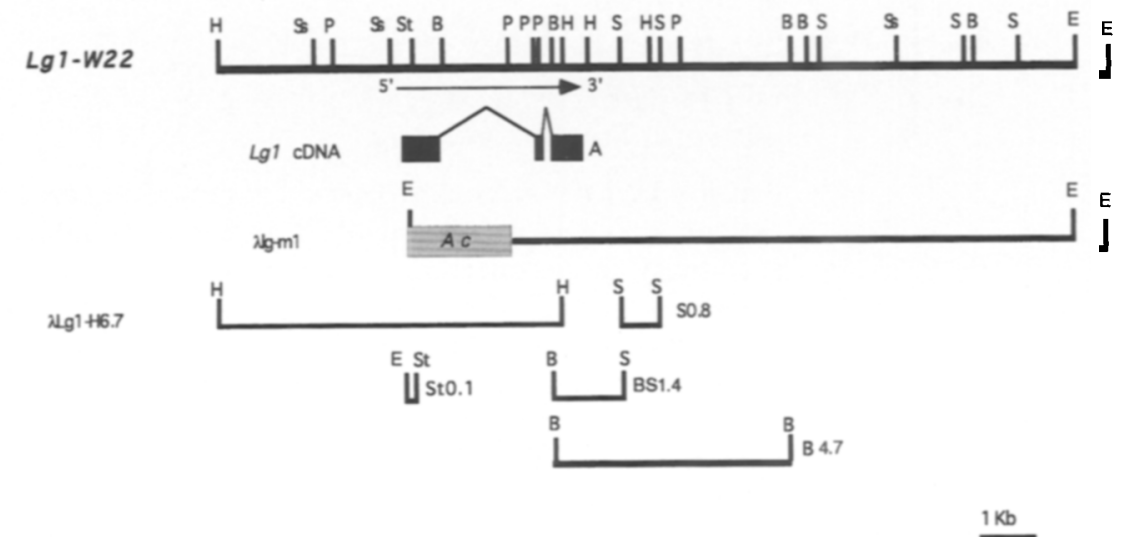

C

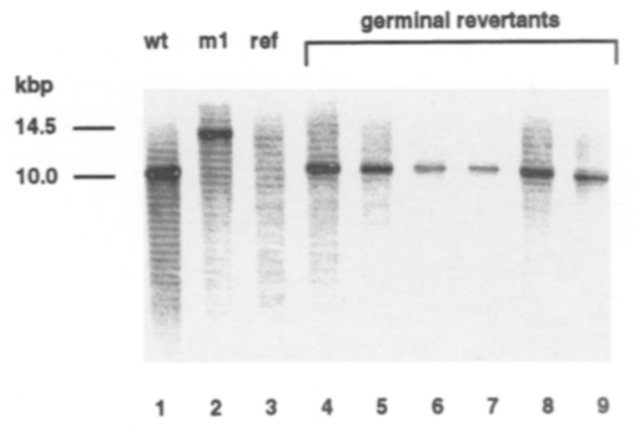

Ac0.9 probe (see Materials and Methods). Lane 1 corresponds to the parental inbredline W22. Lanes 2-5 correspond to plants showing the $1 g 1$ phenotype. Lanes 6-9 correspond to wild-type siblings. A novel $14.5-\mathrm{kb}$ band, representing $t r-A c$ segregates with the $\lg 1$ phenotype. $(B)$ The restriction map of the $L G 1$ region. (Top) The restriction map of the genomic DNA in the W22 $\mathrm{LG}^{+}$allele. (Bottom) The corresponding $\lambda L G 1$ and $\lambda \lg 1-\mathrm{m} 1$ clones. In the $\lambda \lg 1-\mathrm{ml}$ map, the shaded box represents the fragment of the $A c$ element present in the clone. The positions of probes derived from these clones are indicated below the restriction map. The position of the cDNA is indicated by the solid boxes just below the restriction map. The arrow indicates the direction of transcription of the $L G 1$ gene. $(C)$ A Southern blot analysis of $L G 1^{*}$ germinal revertants. Genomic DNA was isolated from several independent $L G 1^{*}$ germinal revertants of genotype $L G 1^{*} / \lg 1$ $R$. The DNA was digested with the enzyme SstI and analyzed by Southern blotting with the S0.8 probe. (Lane 1) The wild-type W22 LG1 allele; (lane 2) the $1 g 1$ $m 1$ allele; (lane 3 ) the $1 g 1-R$ allele; (lanes 4-9) six independent germinal revertant alleles. (H) HindIII; (Ss) SstI; (P) PstI; (B) BamHI; (S) SalI, (E) EcoRI; (St) StyI. seven positive signals. The sizes of these cDNAs ranged from 0.4 to $1.3 \mathrm{~kb}$, and their sequences were colinear with specific regions of $\lambda \lg 1$, a genomic clone of $\lg 1$. DNA sequence analysis of seven of the cDNAs revealed two alternative polyadenylation sites at 163 and $220 \mathrm{bp}$ downstream of the stop codon. DNA sequence analysis of the longest cDNA obtained, $\lambda \mathrm{C} 3$, showed that this cDNA spans two introns and comprises the majority of the sequence present in the H6.7 probe. Translation of the C3 DNA sequence revealed one 1180-bp open reading frame (ORF) that lacked a starting ATG and ended with a TAG 163 bp upstream of the poly|A) tail.

To identify an ATG that could encode for the first amino acid of the LG1 protein, a population of cDNAs representing mRNA from developing ligules was extended by PCR. The primer used (pLG1-1) was complementary to a sequence located 70 bp downstream of the $5^{\prime}$ end of clone $\lambda \mathrm{C} 3$. The size of the extended cDNA is $1411 \mathrm{bp}$. Translation of the extended cDNA revealed a 1200-bp ORF that begins with the first ATG present within the CDNA sequence and ends with a TGA 163 bp upstream of the poly(A) tail. However, we do not have data that exclude unequivocally sequences upstream of the first ATG from the being coding sequence. The amino acid sequence of the predicted LGI protein is shown in Figure 4A. The expected mo- 
lecular size of this product is $43.36 \mathrm{kD}$ and its estimated $\mathrm{pI}$ is 7.72 .

We find it reassuring that our estimated protein, encoded by $1.2 \mathrm{~kb}$ of message, might be expected to be carried in a message $\sim 1.4 \mathrm{~kb}$ in length. From gel fractionation of poly $(\mathrm{A})^{+}$RNA followed by an RT-PCR assay and controlled by mRNA isolated from a deletion allele of $\lg 1, L G 1$ mRNA was estimated to be in the range of $1.0-1.4 \mathrm{~kb}$ in length (B. Kloeckner-Gruissem, pers. comm.).

Comparison of the predicted LG1 amino acid sequence in the GenBank database using the FASTA (Pearson and Lipman 1988), BLOCKS (Henikoff and Henikoff 1991), and the Wisconsin Sequence Analysis Package programs, revealed no significant overall homology to known proteins. However, an internal 77 -amino-acid region of the LG1 predicted sequence has $75 \%$ identity and $82 \%$ similarity with a shared 79 -amino-acid stretch at the carboxy-terminal region of $A$. maius SBP1 and SBP2 (Fig. $4 B$ ). The 79-amino-acid stretch shared by SBP1 and SBP2 has been shown recently to contain the region necessary

A

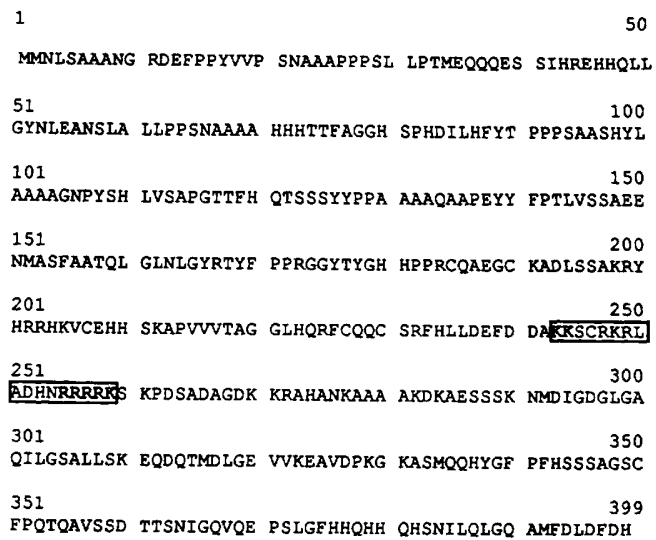

B

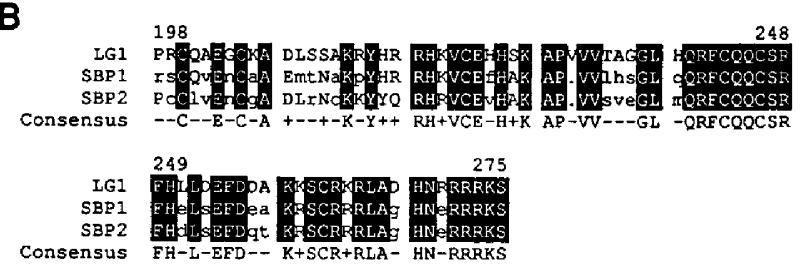

Figure 4. Predicted amino acid sequence of the LG1 protein. (A) The predicted amino acid sequence of the LG1 protein. The basic bipartite NLS is boxed. The conserved basic amino acids in the NLS are indicated in boldface type. $(B)$ A PILEUP alignment (Higgins and Sharp 1989) of the internal 77-amino-acid region of the LG1 protein with the DNA-binding domain of SBP1 and SBP2. Indicated in lowercase letters are those amino acids that differ among the three sequences. Similarly, conserved amino acids are shown in the solid boxes. The consensus sequence was generated with the PRETTY program in the GCG package. Invariant residues in all three sequences are indicated in uppercase letters, and conservative changes are indicated by a plus $(+)$ sign. for binding of these proteins to a DNA element present in the SQUAMOSA gene promoter (Klein et al. 1996). This region also contains a putative bipartite nuclear localization signal (NLS).

A less significant similarity found in the database search is a histidine-rich, or CAX, repeat at the carboxyl terminus of the LG1 protein. This repeat is present in several developmentally important eukaryotic proteins; however, its function is not yet determined (Poole 1985; Wharton 1985; Mlodzick and Gehring 1987; LaRosa and Gudas 1988; Vollbrecht et al. 1991). A search for functional protein motifs using the PROSITE Dictionary of Protein Sites and Patterns by (A. Bairoch, University of Geneva, Switzerland) unveiled four possible casein kinase II (CK-2) phosphorylation sites, as well as one cAMP- and cGMP-dependent protein kinase phosphorylation site. However, experiments to determine whether these sites are phosphorylated in the LG1 protein need to be performed.

\section{LG1 mRNA is expressed in the ligular-region blade and sheath of primordial leaves}

Because LG1 mRNA expression could not be detected on Northern blots or in situ, RT-PCR was used. To increase specificity, a $\lg 1$-specific $3^{\prime}$ primer was used for the cDNA synthesis (pLg1-4; see Materials and Methods) and a nested $3^{\prime}$ primer for the PCR reaction (pLg1-8). In addition, the PCR primers pLg1-8 and pLg1-6 were designed to span an intron to distinguish between PCR amplification from cDNA versus possible contaminating genomic DNA. A product of 475 bp was expected from $\lg 1$ cDNA, whereas a product of $700 \mathrm{bp}$ was expected from $\lg 1$ genomic DNA.

To test whether the RT-PCR method would detect LG1 mRNA, poly (A) $)^{+}$RNA was isolated from the dissected meristem plus primordia (see Materials and Methods) of $\lg 1-R$ mutants and their wild-type siblings. After DNase treatment, this RNA was subjected to RT-PCR, and a product of 475 bp was detected in wild type, whereas no product was detected in samples from the sibling $\lg 1-R$ deletion allele homozygotes. The 475-bp product was gel purified and sequenced. The sequence of the RT-PCR product was found to be identical to the sequence of the cloned $\lg 1$ cDNA (data not shown). This confirmed that the RT-PCR method detects the rare LG1 transcript.

To localize LG1 mRNA expression, 2-week-old seedlings were dissected as follows: The first three leaves were removed from the shoot, and each was divided into three fractions: $1 \mathrm{~cm}$ of blade directly above the ligular region, the ligular region itself, and $1-10 \mathrm{~mm}$ of sheath directly below the ligular region. The size of each fraction depended on which leaf it came from (leaf one, two, or three), and sizes were consistent for each type of leaf. Leaf one is the oldest leaf and is the first leaf after the coleoptile. The remaining shoot, which included the meristem and the bases of the six youngest leaves (P1-P6), was the dissected meristem plus primordia, and was retained as a single fraction. One centimeter of root was 
also taken from each seedling. RT-PCR was performed several times on total RNA from these 11 fractions. To ensure that each RNA sample was intact and able to be reverse transcribed, a control RT-PCR was run on every RNA sample using primers specific to maize ubiquitin. Figure 5C shows this control on the identical RNA samples that were used for Figure 5B. For further controls, RT-PCR was also performed on total RNA from $\lg 1-R$ homozygotes "dissected meristem plus primordia", water (negative control), and genomic DNA (positive control). PCR was also run on all samples and no amplification resulted, indicating all PCR amplification was cDNA dependent (data not shown).

The developmental stage of the first three leaves used in the RT-PCR expression experiments is shown in Figure 5A. The first leaf was the ninth leaf from the meristem, which we call $\mathrm{P} 9$. This leaf is fully expanded and mature. The second leaf is P8 and is completing its ba-

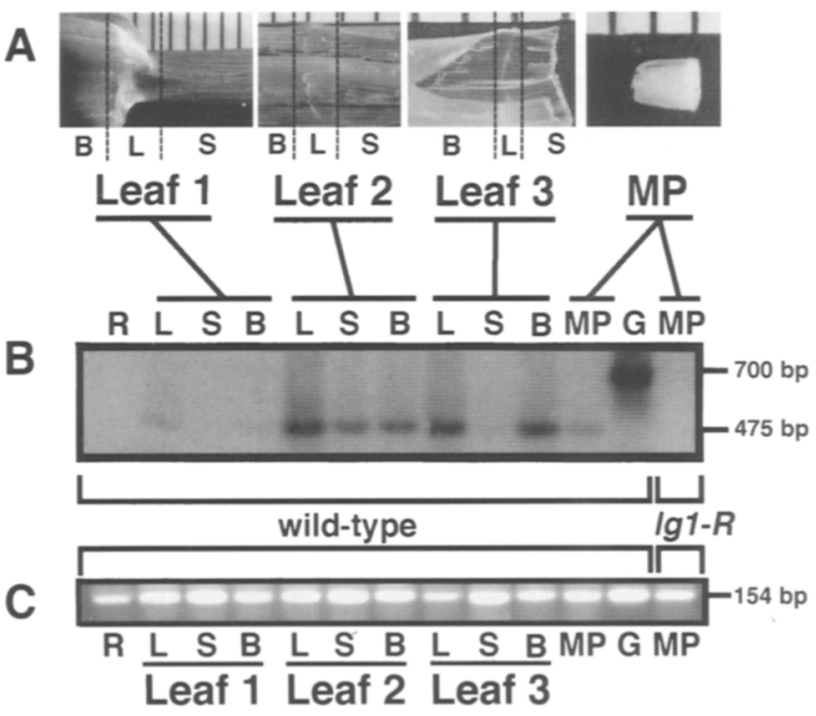

Figure 5. RT-PCR-mediated localization of $L G 1$ mRNA. Three successive leaves, the remaining shoot, and the root were dissected from 300 seedlings. RNA was extracted and RT-PCR was performed on each fraction. (A) Photographs of representative leaves and dissected meristem plus primordia (MP) /see Materials and Methods). A ruler (in $\mathrm{mm}$ ) is present on each photograph. The vertical broken lines represent approximate positions where the leaves were cut. (B) blade; (L) ligular region; (S) sheath. (B) A typical Southern blot of PCR results using lg1-specific primers hybridized to the H/P400 lg1 cDNA probe. The first 11 lanes are RT-PCR products from RNA isolated from specific parts of wild-type shoots, as indicated by lines to the photographs in $A$. The 475 -bp product is expected from $\lg 1$ cDNA. The G lane shows the PCR product from wild-type genomic DNA. Because the lg1-specific primers span an intron, the 700-bp product is expected from genomic DNA. The last lane shows no RT-PCR product from RNA isolated from the dissected meristem plus primordia of $1 g 1-R$ plants. $(C)$ An EtBrstained agarose gel of the identical samples subjected to RTPCR using maize ubiquitin control primers under the same conditions (see Materials and Methods). Southern blot analysis has shown that this 154-bp product hybridizes to a ubiquitin probe (data not shown). (B) blade; (L) ligular region; (S) sheath; (MP) dissected meristem plus primordia; $(R)$ roots; $(G)$ genomic DNA. sipetal differentiation. The ligule is about half of its fully expanded size, and the auricle has not yet begun to expand. The third leaf $\mathrm{P} 7$ has begun its basipetal differentiation, but it has not yet reached the ligular region. The preligular band of anticlinal divisions is apparent and has just begun actual ligule outgrowth.

\section{Subcellular localization of a LG1 fusion protein}

To determine where in the cell the LG1 protein is localized, the extended $\lg 1$ cDNA was translationally fused to a modified version of the green fluorescent protein (GFP) (mGFPS65T; see Materials and Methods) (Chalfie et al. 1994; Haseloff and Amos 1995; A. von Armin, unpubl.) of Aequorea victoria driven by the constitutive cauliflower mosaic virus (CaMV) promoter 35S (Bevan 1984). Because of the ubiquitous localization of the GFP throughout the plant cell, several control translational fusions between GFP and the cytoplasmic reporter $\beta$-glucuronidase gene (GUS) (Jefferson 1987) were also investigated. All constructs were bombarded into onion epidermal cell layers via the Helium Biolistic gene delivery system (DuPont) (Klein et al. 1987). Subsequently, the tissues were stained with 4',6-diamidino-2-phenylindole (DAPI), a chromatin-specific stain, and analyzed by fluorescence microscopy or histochemical assays, where appropriate. Results from these experiments are shown in Figure 6.

Several control experiments validated the use of the GFP as a nuclear reporter gene in onion epidermal cells. Cells transformed with GFP alone display diffuse fluorescence throughout the cytoplasm and nucleus (Fig. 6b, panel A). This pattern of GFP compartmentalization can be explained easily by the small size of the GFP alone$26.9 \mathrm{kD}$-small enough to diffuse easily through the nuclear pore without the need for a specific NLS /GarciaBustos et al. 1991). The presence of the GFP both in the cytoplasm and the nucleus suggests that specific distributions of chimeric proteins in either of these compartments would be readily detectable. To confirm that specific localization to the nucleus is possible, localizations of the products of translational fusions between GUS (Jefferson 1987) (Fig. 6a, panel A) and GFP (Fig. 6b, panel A) were compared to that of translational fusions between a modified version of the GUS gene carrying the NLS from the potyviral NIa gene (Carrington et al. 1991) and GFP. The GUS gene was chosen as a marker for these experiments because this $68-\mathrm{kD}$ protein has been shown previously to localize in the cell's cytoplasm by histochemical and biochemical assays (Jefferson 1987; Carrington et al. 1991; Varagona et al. 1992; Arnim and Deng 1994). Example results of these experiments are shown in Figure $6 \mathrm{~b}$ (panels $\mathrm{B}$ and C). Cells that were bombarded with the GFP::GUS construct display diffuse fluorescence throughout the cytoplasm, with some fluorescence surrounding the nucleus (Fig. 6b, panel B). The same tissue was subsequently stained with 5-bromo-4chloro-3-indolyl $\beta$-D glucoronide cyclohexylamine (XGluc) for histochemical localization of the GFP::GUS fusion protein. GUS staining was restricted to the cyto- 
Figure 6. Subcellular localization of the GFP::LG1 fusion protein in onion cells. $(a)$ Subcellular localization of GUS vs. GFP$:: G U S$ and GFP::GUSNIa fusion. $|A|$ The subcellular localization of the GUS protein alone; $(B)$ the subcellular localization of the GFP::GUS fusion protein; $|C|$ the subcellular localization pattern of the GFP::GUSNIa fusion protein. The left column corresponds to visualization of the bombarded cells histochemically stained with X-gluc to localize the GUS protein via Nomarski optics. The right column shows the same cells stained with the nuclear-specific dye DAPI. In all cases, the position of the cell's nucleus is indicated by an arrow. (b) Subcellular localization of the GFP::LGl fusion protein in onion cells. $(A)$ The subcellular localization pattern of the GFP alone; $(B)$ the subcellular localization pattern of the GFP::GUS fusion protein; $(C)$ the subcellular localization pattern of the GFP::GUSNIa fusion protein; $(D)$ the subcellular localization of the GFP::LG1 protein; and $(E)$ the subcellular localization pattern of the GFP::LG1 $(\Delta 116-280)$ protein. In all cases, the position of the cell's nucleus is indicated by an arrow. The left column corresponds to visualization of the bombarded cells with Nomarski optics; the center column shows the same cells stained with the nuclear specific dye DAPI and the right column shows the visualization of the GFP staining. Bars, $50 \mu \mathrm{m}$. a
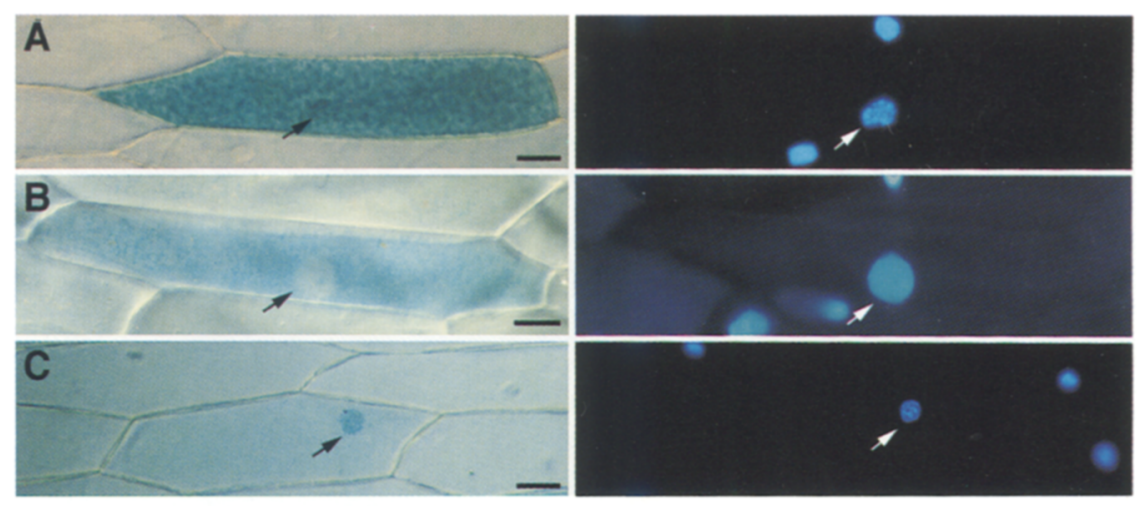

\section{b}
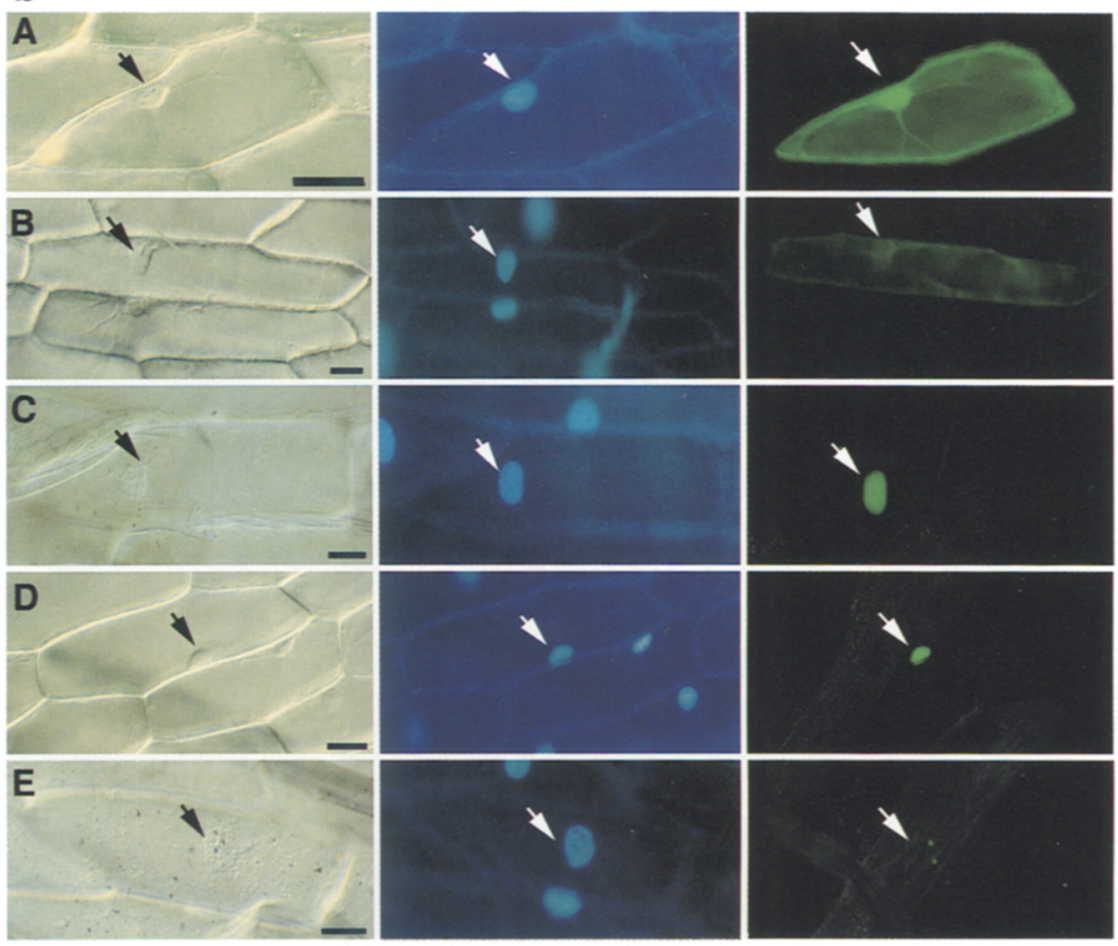

plasmic region of the transformed cells (Fig. 6a, panel B). On the other hand, cells transiently expressing the GFP::GUSNIa protein (Fig. 6b, panel C) showed fluorescence only in the cell's nucleus. The same results were observed when the same tissue sample was subjected to the histochemical assay (Fig. 6B, panel E). This indicates that the addition of the NLS to the cytosolic GUS protein is sufficient to trans-locate this fusion protein to the nucleus, thus validating the use of the GFP as a nuclear marker.

Cells bombarded with a translational fusion of GFP to the $1200-b p$ ORF, referred to herein as the extended $\lg 1$ cDNA, showed that the fluorescence localized exclusively to the cell nucleus (Fig. 5D). Sequence analysis of the predicted LGl protein reveals the presence of a basic region where a putative bipartite NLS is recognized (Fig. 4A) (Hall et al. 1984; Kalderon et al. 1984a,b; Dingwall and Laskey 1991). However, the nuclear localization pat- tern observed for the LG1 fusion protein appears to be influenced by other factors. When cells are bombarded with a construct bearing a fusion of GFP::LG1| $\mid \Delta 116$ 2801 , a deletion that encompasses the 77-amino-acid stretch of homology with SBP1 and SBP2, together with the putative basic bipartite NLS (identified by a bracket in Fig. 4A), the fluorescence is still localized to the cell nucleus although it localized in a "2-dot" particulate pattern (Fig. 5E). This result indicates that remaining sequences present in the GFP::LGl fusion protein must play a role in the nuclear transport of the protein. Experiments to identify such additional signals are in progress.

\section{Discussion}

Molecular cloning of the $\lg 1$ gene

A new mutation that affects the $1 g 1$ gene was isolated via 
a transposon tagging strategy (Dellaporta and Moreno 1994a) that was determined to be allelic to $1 g 1$. Using the $A c$ element as a molecular tag, sequences corresponding to the $\lg 1$ locus were cloned and used as probes to isolate a 1.4-kb $\lg 1$ cDNA. Several criteria confirm that the DNA sequences isolated correspond to the $\lg 1$ gene. First, using DNAs flanking the $A c$ insertion present in the isolated $\lambda \lg 1-\mathrm{m} 1$ clone as probes, we were able to detect the loss of the $A c$ element at $\lg 1-m 1$ in germinal revertant alleles that fully restore $\lg 1$ gene action. Second, the same probes were able to demonstrate that two independently isolated $\mathrm{Mu}$-induced $\lg 1$ mutant alleles are deletions that include at least $12 \mathrm{~kb}$ of $\lg 1$ sequences overlapping our probes. Moreover, the $1 g 1-R$ allele does not contain DNA that hybridizes to these probes, indicating that this mutation also represents a large deletion of the $\lg 1$ gene. Finally, RT-PCR experiments indicated that the sequences present in the $\lambda \lg 1-\mathrm{m} 1$ genomic clone are expressed in the wild-type but not in the $\lg 1-R$ preligular region. In summary, these results provide proof that the $\lg 1$ gene was cloned.

The repeated occurrence of chromosomal deletions for a single-copy gene such as $\lg 1$ is most uncommon. In a directed cross to discover new $\mathrm{Mu}$ transposon insertion alleles, 30,000 plants were screened for the liguleless phenotype. The two mutants recovered were not $\mathrm{Mu}$ insertions at all, but deletions. Perhaps the $\lg 1$ gene happens to be flanked by direct repeats such that intrachromatid homologous recombinations might generate deletions (Athma et al. 1992). Alternatively, there might be something special about the $\lg 1$ region chromosome 2 that increases the known capacity of $\mathrm{Mu}$ excisions to cause deletions (Kloeckener-Gruissem and Freeling 1995).

The LG1 gene product represents a novel class of nuclear-localized proteins. As our results indicate, the LG1 protein does not have significant overall homology to other known proteins. However, there are two subdomains that do show similarity to regions of other proteins. The first domain of 77 amino acids, located in the middle of the protein, shows significant homology $175 \%$ identity, $82 \%$ similarity) to a 79 -amino-acid region present in SBP1 and SBP2 (Klein et al. 1996). This region has been shown to bind a DNA element present in the promoter of the SQUAMOSA gene (Klein et al. 1996). The second domain is a histidine-rich or CAX, repeat present at the carboxyl terminus, which is present in several important eukaryotic proteins known to be regulatory. However, the functional significance of this domain is unknown. From this analysis and its overall amino acid composition, we predict LG1 to be a nuclear regulatory protein, possibly a DNA-binding protein, involved in ligule/auricle induction.

\section{The LG1 message is expressed at very low levels}

The $\lg 1$ gene is required for the proper formation of the ligule and auricles at the blade-sheath boundary of the maize leaf. When this gene product is absent, these structures do not develop in most leaves. Consequently, the leaves display an upright habit of growth. From previous anatomic and morphologic studies, it was proposed that $1 g 1$ first acts in cells in the preligular region, perhaps as early as stage P4 of leaf development, when anticlinal divisions begin (Sharman 1941, 1942; Sylvester et al. 1990). These observations correlate well with the low abundance of the LG1 mRNA found in developing leaves. Approximately, one positive cDNA clone was obtained per $1 \times 10^{6} \mathrm{cDNAs}$ isolated from the developing ligular region that corresponds to the LG1 mRNA. This message has not been detected in Northern blot hybridization experiments, and mRNA in situ localization experiments have also proved unsuccessful.

The LGI mRNA exists predominantly in the ligular region of very young leaves but is also present in nearby sheath and blade

Although the very young (P6) ligule and auricle contain the highest concentration of LGI mRNA, the message is also found throughout the sheath and the blade in the middle of the leaf. Furthermore, LG1 mRNA persists well after ligule and auricle differentiation (Fig. 5). From these data, it may be concluded that the LG1 product alone is not sufficient to induce ligule and auricle. Previous work on the $\lg 1$ mutant phenotype showed that LG1 protein is needed at the cell autonomous (reception) end of the ligule signal transmission-transduction pathway (Becraft et al. 1990), and it is also required for the cell-cell transmission of the make-ligule signal (Becraft and Freeling 1991). Perhaps expression of LG1 precedes the signal and might be conceived as part of the competency of the ligular region to respond to the make-ligule signal. It does make sense that a protein needed to transmit a signal cell to cell should be expressed before the signal emanates and in a larger region than is actually used for the signaling channel.

There are clues as to what other gene products may work with LG1 to induce ligule. There is excellent genetic evidence, based on reciprocal dosage effects and double mutant phenotypes, that LG1 protein works closely with the product of an unlinked gene, liguleless? (Ig2) (Harper and Freeling 1996). It is interesting that the $1 g 2$ phenotype is cell-nonautonomous and has no tissue or regional focus (Harper and Freeling 1996). Homozygotes of $1 g 2-R$ express LG1 message in leaves that do not make ligules (L. Harper, unpubl.). The molecular relationship between LG1 and LG2 is currently under investigation.

The predicted LG1 protein localizes to the cell nucleus in onion cells

As mentioned previously, our attempts to localize the LG1 mRNA in situ have been unsuccessful. Therefore, to determine where in the cell the LG1 product resides, we expressed fusions of $\lg 1$ and GFP transiently in onion bulb (modified leaves) cells. The onion system was chosen for these experiments for the following reasons: (1) Previous studies have shown that the machinery neces- 
sary for nuclear transport of several dicot, monocot, and viral nuclearly localized proteins is functional in onion cells (Restrepo et al. 1990; Carrington et al. 1991; van de Krol and Chua 1991; Varagona et al. 1992; Arnim and Deng 1994); and (2) this assay system facilitated our analysis by allowing examination of several constructs in a short period of time. Our results indicated that the GFP::LG1 fusion protein is localized exclusively to the cell nucleus. Close analysis of the nucleotide sequence of the $\lg 1 \mathrm{cDNA}$ reveals the presence of a putative bipartite basic NLS (for review, see Garcia-Bustos et al, 1991). However, when such sequences are deleted, the GFP::LG1 1 protein still exhibits exclusive nuclear localization. One could explain such an observation by proposing that GFP::LG1 1 , a fusion protein of $52 \mathrm{kD}$ in size is small enough to simply diffuse through the nuclear pore, as it is thought that proteins smaller than $40-60 \mathrm{kD}$ diffuse through the nuclear pore (Garcia-Bustos et al. 1991). If that were the case, we would also expect to see cytoplasmic staining owing to diffusion of the fusion protein out of the nucleus, as is the case with the GFP alone. However, the observation that the GFP::LGls fusion protein seems to be concentrated in two spots in the nucleus, rather than being diffused throughout it, indicates that other sequences besides the bipartite basic NLS sequence in the GFP::LG1 $1 \Delta$ protein play a role in directing this fusion protein to the cell's nucleus. By the same token, the sequences deleted in the GFP::LG1 $1 \mathrm{fu}-$ sion protein play a role is distributing the protein throughout the nucleus as evidenced by the diffuse fluorescence staining when those sequences are present. Therefore, the putative bipartite basic NLS present in the LG1 protein is not the only factor conferring nuclear localization to this protein. It seems likely that the LG1 protein bears a novel NLS or that the protein is transported to the nucleus by cellular factors, homologs of which are also present in the onion cells. Nevertheless, the precise mechanism by which the LGl fusion proteins are trans-located to the nucleus remains to be elucidated.

\section{Possible role of the LG1 protein}

In theory, there are two ways in which the absence of a gene product could remove ligule and auricle. First, because ligule and auricle are organized along an exact line that bisects the leaf, the absence of any protein required to draw the line might remove the ligule. Second, the absence of any protein specific to the differentiation of ligule-auricle might be expected to remove it. Although not conclusive, the data support the former role for LG1. Homozygotes of $l g 1-R$, a deletion allele, do not have a sharp boundary between sheath and blade (Becraft et al. 1990). Double mutant homozygotes of $\lg 1-R$ and $1 g 2-R$ have an even larger region of overlap between sheath and blade, and no ligule or auricle on any leaf (Harper and Freeling 1996). Furthermore, histological observations of the adaxial surfaces of primordial leaves before preligular divisions identified a broad middle region of leaf primordium, a region from which only some cells will eventu- ally divide into ligule or auricle; $1 g 1-R$ homozygotes are normal at this early stage of development (Sylvester et al. 1990|. Thus, it seems likely that LG1, working with LG2 and other proteins, functions to establish an exact line within the preligular region of the primordial leaf. It follows that the liguleless phenotype may reflect the lack of the exact line. If LGl is a transcription factor, then, genes specifically turned on by LG1 function would remain in the cell where they were synthesized /cell autonomy of LG1 function) and would presumably confer ligule or auricle identity. Additional data on the molecular mechanisms in which LG1 and its partners take part will be necessary to test our "no-line, no-ligule" hypothesis.

\section{Materials and methods}

Maize stocks and genetic analysis

$\lg 1-\mathrm{R} \quad \lg 1-\mathrm{R}$ is an allele of $\lg 1$ on chromosome $2 \mathrm{~S}$ showing absence of ligules and auricles in all leaves of the plant. Occasionally, in the upper leaves, ligule vestiges are observed. This allele was obtained from the Maize Genetics Stock Center.

r-sc:m3 r-sc:m3 is a Ds-induced derivative of $R$-sc, an allele of the $R$ locus on chromosome 10L. This allele was used in this study to monitor $A c$ activity. In the presence of an $A c$ element, $r$-sc:m3 conditions a variegated aleurone phenotype. However, in the absence of $A c$, the aleurone shows a colorless phenotype. [This allele was obtained from Dr. J. Kermicle and is described further in Kermicle (1984)].

Recovery of Ac-tagged $\lg 1$ alleles The genetic strategy used to isolate the $A c$-induced $\lg 1$ mutation is described in detail elsewhere (Dellaporta and Moreno 1994a). Briefly, plants homozygous for the $A c$-induced $p 1-v v$ allele were pollinated with males homozygous for the Ds-induced $r$-sc:m3 allele. From this cross, kernels receive one dose of the paternally derived $r$-sc:m3 allele; the embryos of $F_{1}$ kernels are expected to receive one copy of $A C$ from the maternally derived $p 1-v v$ allele, whereas endosperms receive two maternal $p 1-v v$ alleles (endosperm is triploid tissue composed of two maternal and one paternal genomes). Most endosperms of the $\mathrm{F}_{1}$ seed show a typical "two-dose" $r$-sc:m3 response, consisting of numerous colored aleurone spots $(D s$ excisions from $r$-sc:m3|. Transpositions of $A c$ can result in an increase in $A c$ copy number in the genome (Fedoroff 1989). In maize, this increase often results in delayed transpositions of $D s$ because of an AC-negative dosage effect (McClintock 1950). Therefore, kernels enriched for transposed $A c$ elements can be recovered among the $F_{1}$ kernels by scoring endosperms for a very finely spotted or near colorless aleurone phenotype indicative of a higher copy number of Ac. Approximately 4643 kernels showing a finely spotted or near colorless phenotype were recovered among $F_{1}$ kernel progeny, field-grown, and self-pollinated to generated $F_{2}$ seed progeny. Twenty kernels of each $F_{2}$ family were field-grown and screened for segregating mutations. Two families were found to segregate for a liguleless phenotype. As described in Results, one family was shown by genetic criteria to be linked to a transposed $A c$ element.

Allelism tests Allelic complementation tests to the known $1 g 1-R$ allele were performed as follows. Homozygous mutant $\lg 1-\mathrm{m} 1$ plants were crossed as females by homozygous $\lg 1-R$ 
males. The $F_{1}$ seed was sown in greenhouse sand benches, and seedlings were scored for the liguleless phenotype.

Generation of a $\lg 1-\mathrm{m} 1 / \lg 1-\mathrm{R}$ stock for germinal reversion studies Plants homozygous for the $\lg 1-m 1$ allele were testcrossed as females by the $1 g 1-R$ allele to generate $\lg 1-\mathrm{m} 1 / \lg 1-R$ heterozygotes. $F_{1}$ seed was sown in greenhouse sand benches, and seedlings scored for wild-type revertants. Putative revertants were transplanted into pots and grown to maturity. In most cases, plants were self-pollinated and crossed as males onto $x$-sc:m3 homozygous females to score for the loss of the $A c$ element present at $\lg 1-\mathrm{m} 1$. These $1 g 1^{+}$alleles generated by $A c$ excision from $\lg 1-m 1$ were designated $\lg 1^{*}$ followed by sequential numbering.

\section{DNA isolation and Southern analysis}

Maize genomic DNA was isolated from leaf tissue from seedlings and mature plants according to Chen and Dellaporta (1994). Genomic DNA was digested using a threefold excess of restriction enzyme, transferred onto Zeta-probe membranes (Bio-Rad) under alkaline conditions, and analyzed by Southern hybridization (Southern 1975) modifed according to Dellaporta, and Moreno (1994b). The Ac0.9 probe corresponds to an internal HindIII-EcoRI fragment of $A c$ and has been described previously (Fedoroff et al. 1983). The S0.8 probe, a Sall 0.8-kb fragment, was derived from the $\lambda \lg 1-\mathrm{m} 1$ genomic clone. All $\lg 1$ probes are shown in Figure 3B. The DNA fragments were prepared by restriction digestion, purified from low-melting-point (NuSieve) agarose gels using Gelase (Epicentre Technologies), and radiolabeled with $\left[{ }^{32}\right] \mathrm{dCTP}$ (Amersham) by the random priming method (Feinberg and Vogelstein 1984).

\section{Genomic cloning of $\lg 1-\mathrm{m} 1$ and $\lg 1$ sequences}

Cloning of $\lg 1-\mathrm{m} 1$ For purposes of cloning, we identified an EcoRI fragment of $14.5 \mathrm{~kb}$ in size that cross-hybridized with the Ac0.9 probe and cosegregates with the $1 g 1-\mathrm{m} 1$ mutation. Genomic libraries were prepared with EcoRI-digested W22 $1 g 1-m 1$ DNA, size-fractionated on glycerol gradients (Sambrook et al. 1989|. The 12- to $18-\mathrm{kb}$ size fraction was ligated to $\lambda$ DASH II (Stratagene) arms digested previously with EcoRI and BamHI according to the manufacturer's instructions. The ligation was packaged in vitro using Gigapack Gold II (Stratagene) and plated on the Escherichia coli strain ER1647 (New England Biolabs). Approximately $8 \times 10^{6}$ primary recombinants were screened with the Ac0.9 probe. The primary signals were picked, and DNA was isolated and analyzed by Southern blots to identify clones that contained the previously identified 14.5-kb EcoRI fragment that cross-hybridizes with Ac. From a total of 170 primary signals analyzed, only 1 contained the correct insert. DNA was isolated from the plaque-purified clone by standard procedures (Sambrook et al. 1989). A restriction map of the $\lambda$ clone was generated by partial restriction mapping (Sambrook et al. 1989), and several restriction fragments were subcloned into the phagemid pBS KS $|+|$ |Stratagene).

Cloning of $\lg 1$ An amplified HindIII total genomic library in the vector $\lambda$ NM1149 (S. Dellaporta, unpubl.) was screened with the probe SB1.4. DNA was isolated from plaque-purified clones, mapped, and subcloned as described previously. The probe SB1.4 corresponds to a SalI-BamHI 1.4-kb fragment from $\lambda \lg 1$ $\mathrm{ml}$ and is depicted in Figure 3B.

\section{Isolation of $\lg 1$ cDNA clones}

Total RNA was isolated from developing ligules, in the inbred line W22, at P4-P7 by LiCl extraction (Van Tunen et al. 1988). Poly $(A)^{+}$RNA was purified on Dynabeads (Dynal) according to the manufacturer's instructions. cDNA was synthesized using the Time Saver Plus cDNA Kit (Pharmacia) and ligated to dephosphorylated EcoRI $\lambda$ gt 10 arms (Promega). The ligation was packaged in vitro using Gigapack Gold II (Stratagene), and the phage were plated on E. coli $\mathrm{C} 600 \mathrm{Hfl}$ (Promega). Approximately $8 \times 10^{6}$ primary recombinants were screened with the probe H6.7 (Fig. 3B), and seven positive clones were obtained. DNA was isolated from plaque-purified clones as described above. Inserts from the cDNA clones were purified in low-meltingpoint agarose (NuSieve) by Gelase (Epicentre Technologies) and subcloned into the EcoRI site of the vector pBSII KS. The largest lg1 cDNA clone isolated from this library contained a $1.3-\mathrm{kb}$ insert. The nucleotide sequence of both strands of cDNA clones was determined using Sequenase 2.0 (U.S. Biochemical) according to the manufacturer's instructions. Sequencing reactions were also performed by Karl Hager (Keck Foundation, Yale University, New Haven, CT) and by Millicent Yee (University of California-Berkeley Sequencing Facilityl.

\section{$5^{\prime}$ RACE analysis}

Two micrograms of poly $(A)^{+}$RNA were reverse transcribed using 10 pmoles of primer pLG1-2. After hydrolysis of the RNA template with $\mathrm{NaOH}$, first-strand cDNA was purified with GENO-BIND (Clonetech Labs, Inc.) to remove excess primer. The cDNA was concentrated by ethanol precipitation. A commercially available single-stranded anchor oligonucleotide (Clonetech Labs, Inc.) was ligated to the 3' end of the cDNA. Following ligation, an aliquot of the resulting product was used as a template for PCR amplification using a primer specific to the anchor, AP, and a second nested primer specific to $\lg 1$, pLG1-1. The PCR conditions were as follows: a 3-min incubation at $95^{\circ} \mathrm{C}$ was followed by 35 cycles of $45 \mathrm{sec}$ at $95^{\circ} \mathrm{C}, 45 \mathrm{sec}$ at $60^{\circ} \mathrm{C}, 2 \mathrm{~min}$ at $72^{\circ} \mathrm{C}$, and a final extension of $7 \mathrm{~min}$ at $72^{\circ} \mathrm{C}$. Previous to cycling, all samples were subjected to a hot start by incubating all reaction components breifly, except primers and enzyme, for $2 \mathrm{~min}$ at $95^{\circ} \mathrm{C}$. The PCR products obtained were analyzed by Southern hybridization to the probe St0.1 (Fig. 3B). PCR products were cloned into the plasmid vector pT7Blue (Novagen, Inc.), and the double-stranded sequence of 13 independent clones was determined.

Primers The oligonucleotide primers used in these studies were as follows: pLG1-1, 5'-TCCTGCTGCTGCTCCATGGTTGGGAG-3'; pLG1-2, 5'-CTCGAGGTTGTAGCCCAGCAGCTGA-3'; and anchor primer (AP), 5'-CTGGTTCGGCCCACCTCTGAAGGTTCCAGAATCGATAG-3'; and anchor sequence, 5'GGAGACTTCCAAGGTCTTAGCTATCACTTAAGCAC-3'.

\section{RT-PCR analysis}

Tissue samples for RNA preparation Two-week-old seedlings of families segregating $1: 1$ for $\lg 1-R / \lg 1-R$ and $+/ \lg 1-R$ introgressed into Mo17, were used as the source for RNA. To test whether the RT-PCR method would detect LG1 mRNA, poly $(\mathrm{A})^{+}$RNA was isolated from the following tissue. The coleoptile and first two leaves were removed from the seedlings. The remaining shoot was then cut below the meristem and cut above the developing ligule of the third leaf. This left a 2- to $5-\mathrm{mm}$ stub that included the whole shoot meristem, all axillary buds from the second node on, and six or seven leaf primordia/ 
primordia bases at various stages of development. All leaf primordia/primordia bases on this stub contained their developing ligule and auricle. We will refer to this stub as the dissected meristem plus primordia.

To localize LG1 mRNA expression, $300 \mathrm{Mo} 17+/+$ seedlings were dissected as follows: The first three leaves were removed, and each was divided into three fractions, $1 \mathrm{~cm}$ of blade directly above the ligular region, the ligular region itself, and 1-10 $\mathrm{mm}$ of sheath directly below the ligular region. The size of each fraction depended on which leaf it came from (leaf one, two, or three); sizes were consistent for each type of leaf. Leaf one is the oldest leaf and is the first leaf after the coleoptile. The remaining shoot, which included the meristem and the bases of the six youngest leaves (P1-P6), was dissected as the dissected meristem plus primordia and was retained as a single fraction. One centimeter of root was also taken from each seedling.

Isolation of RNA RNA extractions were performed using Trizol (GIBCO-BRL) according to the manufacturer's instructions. Poly $(\mathrm{A})^{+}$RNA, when used, was isolated from dissected meristem plus primordia according to Kloeckener-Gruissem et al. (1992). RNA, either poly $(\mathrm{A})^{+}$or total, was subjected to DNase treatment using RQ RNase-free DNase (Promega) in $1 \times$ Superscript reverse transcriptase II first-strand buffer for $1 \mathrm{hr}$.

$R T-P C R$ The RT-PCR protocol was worked out using dissected meristem plus primordia mRNA. The protocol was considered successful when detection of a reverse transcription (RT)- dependent PCR product was found in wild-type siblings, but absent from $\lg 1-R$ mutants that contain a deletion of $\lg 1$ genomic sequences. Two micrograms of poly $(\mathrm{A})^{+}$RNA or $25 \mu \mathrm{g}$ of total RNA were reverse transcribed using $2 \mu$ of Superscript reverse transcriptase II (GIBCO-BRL) according to the manufacturer's instructions. For the 191 -specific RT-PCR, the oligonucleotide pLG1-4 was used as the $3^{\prime}$ primer for the first-strand cDNA reaction. For the ubiquitin-specific RT-PCR, the oligonucleotide ub4 was used as the 3' primer for the first-strand cDNA reaction. Following reverse transcription, a $2 \mu 1$ aliquot of the RT reaction was subjected to PCR amplification using 20 pmoles of the 5' primer, (pLG1-6 or ub1), and 20 pmoles of the nested 3' primer (pLG1-8 or ub2). Other components of the PCR reaction mixture were $2 \mu \mathrm{l}$ of $1 \mathrm{~mm}$ dNTPs, $2 \mu \mathrm{l}$ of $10 \times$ PCR buffer (Perkin Elmer Cetus), $10 \mu$ of water, and $15 \mu$ l Chill-out 14 wax (MJ Research, Inc.). The reaction was placed on ice until the wax solidified. Then, $1 \mu 110 \times$ PCR buffer (Perkin Elmer Cetus), $8.6 \mu$ l water, and 2.0 units of Amplitaq DNA polymerase (Perkin Elmer Cetus ) were added, and the reaction was placed in a hot PCR machine with oil in the wells. The PCR cycling conditions included the following three cycling steps. The first cycling program included three cycles of $30 \mathrm{sec}$ at $96^{\circ} \mathrm{C}$ followed by an extension period of $2 \mathrm{~min}$ at $72^{\circ} \mathrm{C}$. The second cycling program consisted of three cycles of $96^{\circ} \mathrm{C}$ for $30 \mathrm{sec}, 1 \mathrm{~min}$ at $65^{\circ} \mathrm{C}$, and $1 \mathrm{~min}$ at $72^{\circ} \mathrm{C}$. The third cycling program included 25 cycles of $30 \mathrm{sec}$ at $96^{\circ} \mathrm{C}, 1 \mathrm{~min}$ at $60^{\circ} \mathrm{C}$, and $1 \mathrm{~min}$ at $72^{\circ} \mathrm{C}$ and a final extension of $6 \mathrm{~min}$ at $72^{\circ} \mathrm{C}$. Samples were kept at $4^{\circ} \mathrm{C}$ after amplification. The $\lg 1$-specific RT-PCR and ubiquitin-specific RT-PCR were both performed using identical amounts of starting RNA and identical amplification conditions. The results shown in Figure 5, B and C, are from the identical series of RNAs.

Following amplification, the PCR products were analyzed by gel electrophoresis on $3 \%$ NuSieve plus $1 \%$ agarose gels in $1 \times$ TBE buffer. Southern blot analysis was performed according to Sambrook et al. (1989).
Primers All primers used in these experiments were designed with Mac Vector software. The efficiency of the sequences selected to serve as primers was double checked using the program AMPLIFY (Engels 1993). Ubiquitin primers were designed based on the sequence reported in Christensen et al. (1992). The lg1 primer pairs were chosen such that they span intron 2 of the cDNA to allow discrimination between PCR products from genomic DNA (700-bp product), versus products from cDNA (475bp product). To increase the specificity of the PCR reaction, a set of nested primers at the $3^{\prime}$ end was used. For the $\lg 1$-specific RT-PCR, the primer used for the reverse transcription, pLG1-4, is 62 bp downstream of the $3^{\prime}$ primer used for the PCR reaction, pLG1-8. The sequences of the PCR primers were as follows: pLG14, 5'-GCACAAACAAGATAGAGGGGAGG-3'; pLG1-6, 5' -TTCGACGATGCTAAGAAGAGCTG-3'; and pLG1-8, 5' -AAGTCGAGATCAAACATAGCCTGG-3'; ub1, 5'-GACCATAACCCTGGAGGTTGAGAGC-3'; ub2, 5' - GGATGTTGTAGTCTGCTAGGGTGCG-3'; and ub4, 5' - CTGAAAGACAGAACATAATGAGCACAGGC-3'.

DNA isolation and sequencing RT-PCR products were purified from agarose gel slices for sequencing using a Qiaquick gel extraction kit (Qiagen, Inc.). Sequencing reactions were performed by Millicent Yee.

\section{Microprojectile bombardment of onion tissues}

The Helium Biolistic gene transformation system (Du Pont) was used to transform onion epidermal cell layers with GFP, GFP::LG1, GFP::LG1 $(\Delta 116-280)$, GFP::GUS, and GFP::GUSNIa translational fusion constructs according to Varagona et al. (1992). Gold particles were coated with the appropriate plasmid DNA by precipitation according to Ludwig et al. (1990). The tissue was bombarded and incubated in the dark at $25^{\circ} \mathrm{C}$ for 24 hr. The colorimetric X-Gluc assay was used to determine the cellular localization of the GFP/GUS and GFP/GUSNIa fusion proteins (Jefferson 1987). The subcellular localization of the Lgl/GFP, and other GFP fusion proteins was determined by fluorescence microscopy (FITC filter set: 450 - to $490-\mathrm{nm}$ excitation, 515- to $565-\mathrm{nm}$ emission). Subcellular localization of the blue precipitate (in the case of the GFP/GUS and GFP/GUSNIa fusions) and of the Lg1/GFP fusion protein was compared with the localization of DAPI-stained nuclei using fluorescence optics (DAPI filter set: $365-\mathrm{nm}$ excitation; emission, $420 \mathrm{~nm}$ and above). All transformation experiments were done in triplicate, and the experiment was repeated three times. The subcellular localization of each of the fusion proteins described was scored when $99 \%$ of the cells hit showed the same flourescence and/or histochemical staining pattern in each sample.

\section{Plasmids}

The plasmids pRTL2-GUS, pRTL2-GUSNIa, and pRTL2GUSNIa $\triangle B a m H I$ were a generous gift from J.C. Carrington and are described in detail elsewhere (Carrington et al. 1991).

MGFP MGFP, a plasmid carrying a modified version of the GFP (Chalfie et al. 1994), which has been shown to be functional in plant cells, was obtained from J. Hasseloff (Haseloff and Amos 1995).

GFPS65T GFPS65T, a plasmid bearing the modified GFP in which the chromophoric Ser-65 was replaced by a threonine residue, was obtained as a generous gift from R.Y. Tsien and R. Heim and is described further in Heim et al. (1995). 
mGFPS65T The vector containing this double mutant version of the GFP was obtained from A. von Armin (University of Tennessee, Knoxville). This GFP was used for all of the fusion constructs discussed in this paper for the spectral properties of this modified protein allowed for individual detection of GFP as well as DAPI in a doubly stained specimen.

mGFPS65T::GUS The plasmid pRTL2-GUS was digested with the restriction enzymes $\mathrm{NcOI}$ and $\mathrm{BamHI}$ (New England Biolabs) following treatment with Klenow enzyme (New England Biolabs) to obtain a $1.8-\mathrm{kb}$ blunt-ended fragment that contained the GUS gene. The fragment was subcloned into pRTL2mGFPS65T digested previously with BgIII (New England Biolabs) and treated with Klenow enzyme. The resulting plasmid, pRTL2mGFPS65T::GUS, is referred to herein as GFP::GUS

mGFP::GUSNIa The plasmid pRTL2-GUSNIa $\Delta$ BamHI was digested with the enzymes $\mathrm{NcOI}$ and $\mathrm{BamHI}$ (New England Biolabs) and treated with Klenow enzyme (New England Biolabs) to generate a blunt-ended fragment of $-2.2 \mathrm{~kb}$ in size containing a transcriptional fusion between GUS and the NIa genes. This fragment was then subcloned into pRTL2mGFPS65T digested previously with BgIII (New England Biolabs) following treatment with the Klenow enzyme. The resulting plasmid, pRTL2mGFP::GUSNIa, is referred to herein as GFP::GUSNIa.

mGFPS65T::LG1 The extended LG1 cDNA was digested with the enzymes Asp718 (Boehringer and Mannheim) and Sall (New England Biolabs) following treatment with the Klenow enzyme (New England Biolabs) to generate a blunt-ended fragment of $\sim 1.4 \mathrm{~kb}$ in length. This fragment was subcloned into pRTL2mGFPS65T digested previously with BgIII (New England Biolabs) and treated with Klenow enzyme. The resulting plasmid, pRTL2mGFP::LG1, is referred to as GFP::LG1.

mGFPS65T::LG1(D116-280) The extended LG1 cDNA was digested with the enzyme PstI (New England Biolabs) followed by treatment with T4 DNA Polymerase (New England Biolabs) to create a blunt end. Then, the resulting fragments were digested with the enzyme SmaI, and the digested DNA was religated to recover a plasmid bearing the internal deletion encompassing amino acids $116-280$ in the LG1 predicted protein. pLG1| $\Delta 116$ 280 ) was then digested with the enzyme Asp718 (Boehringer and Mannheim) and treated with Klenow enzyme (New England Biolabs) to generate a $1.0-\mathrm{kb}$ blunt-ended fragment. This fragment was subcloned into pRTL2mGFPS65T digested previously with BglII (New England Biolabs) and treated with Klenow enzyme. The resulting plasmid, pRTL2mGFP::LGl $(\Delta 116-280)$ is referred to as GFP::LG1 $(\Delta 116-280)$.

\section{Note}

The LG1 sequence reported in this paper has been submitted to GenBank under accession number U89496.

\section{Acknowledgments}

We thank Heather Ryback, Alejandro Calderon-Urrea, and Lisa Shuster for technical assistance and the remaining members of the Dellaporta laboratory for helpful discussions and technical assistance during the makings of this work. We also thank A. von Arnim for the various plasmids supplied for the bombardment experiments, and Mark Osterlund for help with the GUS assays. We thank Mark Mooney, Lynne Jesaitis, and Barbara Kloeckener-Gruissem for help with cDNA sequencing, and Bar- bara Kloeckner Gruissem for sharing unpublished data on LG1 mRNA size, LG1 homologies, and for helpful scientific discussions throughout the progress of this work. We also thank Dr. Catherine Mackey and DeKalb Plant Genetics for their support. M.A.M. was supported by a National Science Foundation Minorities Research postdoctoral fellowship (BIR-9406827). This work was supported by grants to S.L.D. from the National Institutes of Health (GM38148) and to M.F. from the Department of Energy (DE-FG03-91ER20028).

The publication costs of this article were defrayed in part by payment of page charges. This article must therefore be hereby marked "advertisement" in accordance with 18 USC section 1734 solely to indicate this fact.

\section{References}

Athma, P., E. Grotewold, and T. Peterson. 1992. Ac induces homologous recombination at the maize $P$ locus. Genetics 128: $163-173$.

Becraft, P.W. and M. Freeling. 1991. Sectors of liguleless-1 tissue interrupt an inductive signal during maize leaf development. The Plant Cell 3: 801-807.

Becraft, P.W., D.K. Bongard-Pierce, A.W. Sylvester, R.S. Poething, and M. Freeling. 1990. The Liguleless-1 gene acts tissue specifically in maize leaf development. Dev. Biol. 141: 220 232.

Bevan, M. 1984. Binary Agrobacterium vectors for plant transformation. Nucleic Acids Res. 12: 8711-8721.

Carrington, J.C., D.D. Freed, and A.J. Leinicke. 1991. Bipartite signal sequence mediates nuclear translocation of the polyviral NIa protein. The Plant Cell 3: 953-962.

Chalfie, M., Y. Tu, G. Euskirchen, W.W. Ward, and D.C. Parcher. 1994. Green fluorescent protein as a marker for gene expression. Science 263: 802-805.

Chen, J. and S.L. Dellaporta. 1994. Urea based plant DNA minipreps. In The maize handbook (ed. M. Freeling and V. Walbot), pp. 526-527. Springer-Verlag, New York, NY.

Christensen, A.H., R.A. Sharrock, and P.H. Quail. 1992. Maize polyubiquitin genes: Strucyurethermal perturbation of expression and transcript splicing, and promoter activity following transfer to protoplasts by electroporation. Plant $\mathrm{Mol}$. Biol. 18: 675-689.

Dellaporta, S.L. and M.A. Moreno. 1994a. Gene tagging with Ac/Ds elements in maize. In The maize handbook (ed. M. Freeling and V. Walbot), pp. 219-233. Springer-Verlag, New York, NY.

1994b. Southern blot hybridization. In The maize handbook (ed. M. Freeling and V. Walbot), pp. 569-571. SpringerVerlag, New York, NY.

Dingwall, C. and R.A. Laskey. 1991. Nuclear targeting sequences-A consensus? Trends Biol. Sci. 16: 478-481.

Emerson, R.A. 1912. The inheritance of the ligule and auricle of corn leaves. Nebr. Agric. Exp. Stn. Annu. Rep. 25: 81-85.

Engels, W.R. 1993. Contributing software to the Internet: The Ampliphy program. Trends Biochem. Sci. 18: 448-450.

Fedoroff, N.V. 1989. Maize transposable elements. In Mobile DNA (ed. D.E. Berg and M.M. Howe), pp. 377-411. American Society for Microbiologists, Washington, D.C.

Fedoroff, N., S. Wessler, and M. Shure. 1983. Isolation of the transposable maize controlling elements $A c$ and Ds. Cell 35: 235-242.

Feinberg, A.P. and B. Vogelstein. 1984. A technique for radiolabelling DNA restriction fragments to high specific activity. Anal. Biochem. (Addendum) 137: 266-267.

Freeling, M. 1992. A conceptual framework for maize leaf de- 
velopment. Dev. Biol. 153: 44-58.

Garcia-Bustos, J., J. Heitman, and M.N. Hall. 1991. Review: Nuclear protein localization. Biochim. Biophys. Acta 1071: 83-101.

Hake, S., M. Bird, M.G. Neuffer, and M. Freeling. 1985. Development of the maize ligule and mutants that affect it. In Plant genetics (ed. M. Freeling), pp. 61-72. A.R. Liss, New York, NY.

Hall, M.N., L. Hereford, and I. Herskowitz. 1984. Targeting of E. coli $\beta$-galactosidase to the nucleus in yeast. Cell 36: $1057-$ 1065.

Harper, L. and M. Freeling. 1996. Interactions of $\lg 1$ and $\lg 2$ function during ligule induction in maize. Genetics 144: $1871-1882$.

Haseloff, J. and B. Amos. 1995. GFP in plants. Trends Genet. 11: $328-329$.

Heim, R., A.B. Cubitt, and R.Y. Tsien. 1995. Improved green fluorescence. Nature 373: 663-664.

Henikoff, S. and J.G. Henikoff. 1991. Automated assembly of protein blocks for database searching. Nucleic Acids Res. 19: $6565-6572$.

Higgins, D.G. and P.M. Sharp. 1989. Fast and sensitive multiple sequence alignment on a microcomputer. Comput. Appl. Biosci. 5: 151-153.

Jefferson, R.A. 1987. Assaying chimeric genes in plants: The GUS gene fusion system. Plant Mol. Biol. Rep. 5: 387-405.

Kalderon, D., W.D. Richardson, A.F. Markham, and A.E. Smith. 1984a. Sequence requirements for nuclear location of simian virus 40 large T-antigen. Nature 311: 33-38.

Kalderon, D., B.L. Roberts, W.D. Richardson, and A.E. Smith. 1984b. A short amino acid sequence able to specify nuclear location. Cell 39: 499-509.

Kermicle, J.L. 1984. Recombination between components of a mutable gene system in maize. Genetics 107: 489-500.

Klein, J., H. Saedler, and P. Huijser. 1996. A new family of DNA binding proteins includes putative transcriptional regulators of the Antirrhinum majus floral meristerm identity gene SQUAMOSA. Mol. \& Gen. Genet. 250: 7-16.

Klein, T.M., E.D. Wolf, R. Wu, and J.C. Sandford. 1987. Highvelocity microprojectiles for delivering nucleic acids into living cells. Nature 327: 70-73.

Kloeckener-Gruissem, B. and M. Freeling. 1995. Transposoninduced promoter scrambling: A mechanism for the evolution of new alleles. Proc. Natl. Acad. Sci. 92: 1836-1840.

Kloeckener-Gruissem, B., J.M. Vogel, and M. Freeling. 1992. The TATA box promoter region of maize Adh1 affects organ specific expression. EMBO I. 11: 157-166.

LaRosa, G. I. and L.J. Gudas. 1988. Early retinoic acid-induced F9 teratocarcinoma stem cell gene ERA-1: Alternate splicing creates transcripts for a homeobox-containing protein and one lacking the homeobox. J. Mol. Cell Biol. 8: 3906-3917.

Ludwig, S.R., B. Bowen, L. Beach, and S.R. Wessler. 1990. A regulatory gene as a novel visible marker for maize transformation. Science 247: 449-450.

McClintock, B. 1950. The origin and behavior of mutable loci in maize. Proc. Natl. Acad. Sci. 36: 344-355.

Mlodzick, M. and W.J. Gehring. 1987. Expression of the caudal gene in the germ line of Drosophila: Formation of an RNA and protein gradient during early embryogenesis. Cell 48: 465-478.

Pearson, W.R. and D.J. Lipman. 1988. Improved tools for biological sequence analysis. Proc. Natl. Acad. Sci. 85: 2444 2448.

Poole, S.J. 1985. The engrailed locus of Drosophila: Structural analysis of an embryonic transcript. Cell 40: 37-43.

Restrepo, M.A., D.D. Freed, and J.C. Carrington. 1990. Nuclear transport of plant polyviral proteins. The Plant Cell 2: 987998.

Sambrook, J., E.F. Fritsch, and T. Maniatis. 1989. Molecular cloning. A laboratory manual. Cold Spring Harbor Laboratory Press, Cold Spring Harbor, NY.

Sharman, B.C. 1941. Development of the ligule of Zea mays L. Nature 147: 641.

- 1942. Developmental anatomy of the shoot of Zea mays. Ann. Bot. 6: 245-283.

Southern, E.M. 1975. Detection of specific sequences among DNA fragments separated by gel electrophoresis. I. Mol. Biol. 98: 503-517.

Sylvester, A.W., W.Z. Cande, and M. Freeling. 1990. Division and differentiation during normal and liguleless-1 maize leaf development. Development 110: 985-1000.

van der Krol, A.R. and N.-H. Chua. 1991. The basic domain of plant B-ZIP proteins facilitates import of a reporter protein into plant nuclei. The Plant Cell 3: 667-675.

Van Tunen, A.J., R.E. Koes, A.R. Spelt, A.R. van der Krol, A.R. Stuitje, and N.M. Mol. 1988. Cloning of two chalcone flavonone isomerase genes from Petunia hybrida: Coordinate, light regulated and differential expression of flavonoid genes. EMBO I. 7: 1257-1263.

Varagona, M.J., R.J. Schmidt, and N.V. Rainkhel. 1992. Nuclear localization signal(s) required for nuclear targeting of the maize regulatory protein Opaque-2. The Plant Cell 4: 12131227.

Vollbrecht, E., B. Veit, N. Sinha, and S. Hake. 1991. The developmental gene Knotted 1 is a member of a maize homeobox gene family. Nature 350: 241-243.

von Arnim, A.G. and X.-W. Deng. 1994. Light inactivation of Arabidopsis photomorphogenic repressor COP1 involves a cell-specific regulation of its nucleoplasmic partitioning. Cell 79: 1035-1045.

Wharton, K.A. 1985. opa: A novel family of transcribed repeats shared by the Notch locus and other developmentally regulated loci in D. melanogaster. Cell 40: 55-62. 


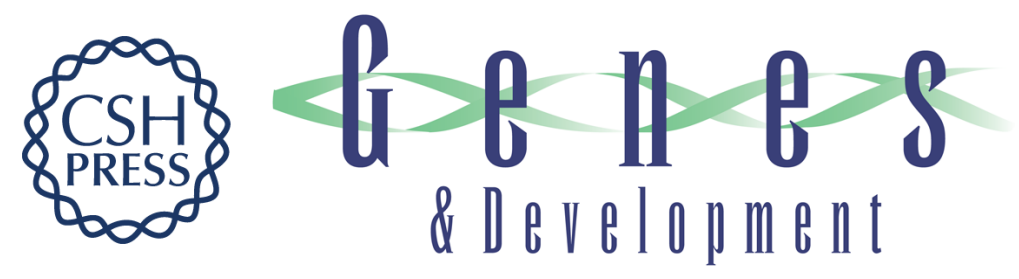

\section{liguleless1 encodes a nuclear-localized protein required for induction of ligules and auricles during maize leaf organogenesis.}

M A Moreno, L C Harper, R W Krueger, et al.

Genes Dev. 1997, 11:

Access the most recent version at doi:10.1101/gad.11.5.616

References This article cites 45 articles, 13 of which can be accessed free at: http://genesdev.cshlp.org/content/11/5/616.full.htmI\#ref-list-1

License

Email Alerting

Receive free email alerts when new articles cite this article - sign up in the box at the top Service right corner of the article or click here.

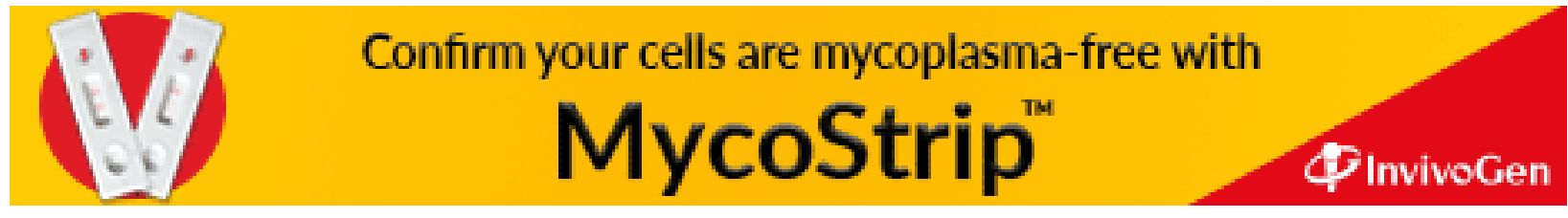

